\title{
AKTIVITAS ANTIOKSIDAN EKSTRAK ETANOL DAN FRAKSI ETANOL-AIR UMBI KIMPUL PUTIH (Xanthosoma sagitafolium L.) DENGAN METODE DPPH
}

\author{
Diana Sylvia ${ }^{1}$, Afni Putri Anggraeni ${ }^{1 *}$, Dina Pratiwi ${ }^{1}$ \\ Sekolah Tinggi Farmasi Muhammadiyah Tangerang \\ Korespondensi: afnianggraeni17@gmail.com
}

\begin{abstract}
ABSTRAK
Umbi kimpul putih (Xanthosoma sagitafolium (L.) Schott. Secara empiris biasa digunakan sebagai bahan obat tradisional. Umbi kimpul putih mengandung senyawa flavonoid dan polifenol yang diyakini dapat berpotensi sebagai antioksidan. Tujuan penelitian ini adalah untuk menentukan kandungan total fenolik dan aktivitas antioksidan ekstrak etanol 96\% dan fraksi etanol-air. Ekstraksi umbi kimpul putih dilakukan dengan metode maserasi dengan pelarut etanol $96 \%$ dan difraksinasi berdasarkan tingkat kepolaran dengan pelarut air, etil asetat dan $n$-heksan. Identifikasi senyawa umbi kimpul putih dilakukan dengan metode skrining fitokimia. Penentuan kandungan total fenolik menggunakan metode Folin Ciocalteau dan pengujian aktivitas antioksidan dilakukan dengan metode DPPH dengan vitamin $\mathrm{C}$ sebagai pembanding. Hasil penelitian menunjukkan bahwa metabolit sekunder yang terdapat pada umbi kimpul putih adalah alkaloid, flavonoid, saponin, tanin dan steroid. Berdasarkan hasil yang diperoleh ekstrak etanol 96\% memiliki kandungan total fenolik sebesar 7,09 mg/g GAE, diikuti fraksi etanol-air sebesar 5,47 mg/g GAE. Berdasarkan hasil perhitungan nilai $\mathrm{IC}_{50}$ ekstrak etanol $96 \%$ memiliki aktivitas antioksidan dengan nilai $\mathrm{IC}_{50}$ sebesar 497,75 ppm, diikuti fraksi etanol-air sebesar 402,36 ppm. Dapat disimpulkan bahwa ekstrak etanol $96 \%$ dan fraksi etanol-air umbi kimpul putih memiliki tingkat kekuatan antioksidan yang sangat lemah.
\end{abstract}

\section{Kata Kunci :Umbi Kimpul Putih, Ekstraksi, Fraksinasi, Antioksidan.}

\begin{abstract}
White tuber bulbs (Xanthosoma sagitafolium (L.) Schott. Empirically used as traditional medicine ingredients. White tuber bulbs contain flavonoids and polyphenols which are believed to have the potential as antioxidants. The purpose of this study was to determine the content of total phenolic and antioxidant activity of ethanol extract $96 \%$ and ethanol-water fraction.The extract of white tuber bulbs was carried out by maceration method with ethanol $96 \%$ solvent and fractionation based on the level of polarity with solvents of water, ethyl acetate and n-hexane.Identification compounds of white tuber bulbs was carried out by phytochemical screening method. The determination of total phenolic content using the Folin Ciocalteau method and Antioxidant activity testing was carried out by the DPPH methodwith vitamin $C$ as a comparison. The results of the observation show that Secondary metabolites found in white tuber bulbs were alkaloids, flavonoids, saponins, tannins and steroids. Based on the results obtained $96 \%$ ethanol extract has a total phenolic content of $7.09 \mathrm{mg}$ I $\mathrm{g} G A E$, followed by ethanol-water fraction of $5.47 \mathrm{mg} / \mathrm{g}$ GAE. Based on the calculation of $\mathrm{IC}_{50}$ value of $96 \%$ ethanol extract has antioxidant activity with $I C_{50}$ value of 497.75 ppm, followed by ethanol-water fraction of $402.36 \mathrm{ppm}$. It can be concluded that $96 \%$ ethanol extract and ethanolwhite kimpul tuber fraction have very weak levels of antioxidant power.
\end{abstract}

Keywords : White tuber bulbs, Extraction, Fractionation, antioxidant 


\section{PENDAHULUAN}

Saat ini Indonesia merupakan salah satu negara penghasil tanaman obat yang potensial dengan keanekaragam hayati yang dimilikinya Keanekaragaman hayati Indonesia menempati urutan ketiga terbesar di dunia setelah Brazil dan Zaire. Jika dilihat dari keragaman floranya, cukup banyak jenis tumbuhan yang dapat dimanfaatkan sebagai tanaman obat. Salah satu jenis umbi yang banyak tumbuh di Indonesia namun belum banyak dimanfaatkan adalah umbi kimpul (Xanthosoma sagittifolium (L.) Schott) (1).

Umbi Kimpul putih (Xanthosoma sagittifolium (L.) Schott) merupakan salah satu dari tiga jenis tanaman talas dari famili Araceae dan merupakan umbi-umbian dari kelompok talas-talasan yang produksinya masih sangat rendah, yaitu hanya $1 \%$ dari seluruh makanan pokok yang dihasilkan dunia. Selain dijadikan sebagai bahan makanan pokok, bahan dasar industri dan diolah menjadi produk ekspor yang komersial (2). Umbi ini juga dapat digunakan sebagai bahan obat tradisional yaitu antara lain menurunkan kadar kolestrol, menurunkan kadar glukosa darah serta mengandung senyawa flavonoid dan polifenol yang berperan sebagai antimikroba dan aktivitas antioksidan (3). Umbi kimpul putih diketahui mengandung senyawa flavonoid, polifenol, saponin, alkaloid, vitamin $\mathrm{C}$, senyawa diosgenin dan kalsium oksalat (1).

Radikal bebas merupakan salah satu bentuk senyawa oksigen reaktif, yang secara umum diketahui sebagai senyawa yang memiliki elektron yang tidak berpasangan oleh karena itu bersifat sangat reaktif dan tidak stabil. Radikal bebas ini juga dapat merusak basa DNA sehingga mengacaukan sistem informasi genetika dan membentuk sel kanker. Radikal bebas juga dapat merusak jaringan lipid sehingga akan terbentuk peroksida dan menimbulkan penyakit degeneratif (4).

Antioksidan adalah senyawa yang dapat menangkal atau meredam dampak negatif oksidan. Antioksidan bekerja dengan cara mendonorkan satu elektronnya kepada senyawa yang bersifat oksidan sehingga aktivitas senyawa oksidan tersebut dapat dihambat. Antioksidan dibutuhkan tubuh untuk melindungi tubuh dari serangan radikal bebas(4).

Metode DPPH ini dipilih karena merupakan metode yang sederhana, cepat, dan mudah untuk skrining aktivitas penangkap radikal beberapa senyawa, selain itu metode ini akurat dan praktis.
Fraksinasi pada prinsipnya adalah proses penarikan senyawa pada suatu ekstrak dengan menggunakan dua macam pelarut yang tidak saling bercampur. Dari proses ini dapat diduga sifat kepolaran dari senyawa yang akan dipisahkan. Sebagaimana diketahui bahwa senyawa-senyawa yang bersifat non polar akan larut dalam pelarut yang non polar sedangkan senyawa-senyawa yang bersifat polar akan larut dalam pelarut yang bersifat polar juga (5).

Berdasarkan uraian diatas maka pada penelitian ini dilakukan uji aktivitas antioksidan ekstrak etanol dan fraksi etanol-air dari umbi kimpul putih (Xanthosoma sagittifolium (L.) Schott) dengan metode DPPH untuk mengetahui perbedaan nilai $\mathrm{IC}_{50}$ terhadap aktivitas antioksidan.

\section{METODE PENELITIAN Bahan}

Bahan yang digunakan didalam penelitian ini adalah umbi kimpul putih yang diperoleh dari desa tenjo, etanol 96\%, etil asetat, n-heksan, Vit $\mathrm{C}$, aquadest, $\mathrm{FeCl} 3, \mathrm{Mg}, \mathrm{HCL}$, Kloroform, metanol, DPPH, H2SO4, asetat anhidrat, pereaksi dragendorf dan mayer, asam galat, reagen Folin Ciocalteau, $\mathrm{Na}_{2} \mathrm{CO}_{3} 15 \%$.

\section{Alat}

Alat yang digunakan dalam penelitian ini antara lain : Alat-alat gelas (pyrex, jerman), Neraca Analitik (Acis, Indonesia), Rotary Evaporator (Buchi Rotavor), Blender, corong pisah, corong kaca, pipet tetes, cawan porselen, tabung reaksi, batang pengaduk dan Spektrofotometer UV-Vis.

\section{Metode \\ a. Perlakuan Terhadap Bahan}

Umbi kimpul putih yang telah diperoleh sebanyak $12 \mathrm{~kg}$ dibersihkan, kulit umbi dikupas kemudian diiris tipis-tipis dan dikeringkan dibawah sinar matahari. Umbi kimpul putih yang telah kering dibuat menjadi tepung dengan menggunakan blender, ditimbang untuk mendapatkan bobot akhir simplisia kemudian disimpan dalam wadah yang kering dan bersih (6).

\section{b. Ekstraksi}

Serbuk simplisia umbi kimpul putih sebanyak 2.450 gram diekstraksi dengan metode maserasi menggunakan pelarut etanol $96 \%$ selama 3x24 jam dalam wadah dan dilakukan 
pengadukan secara berkala kemudian disaring. Maserasi dilakukan sampai filtrat terakhir menjadi jernih. Filtrat yang terkumpul kemudian dipekatkan dengan menggunakan evaporator pada suhu $60-70^{\circ} \mathrm{C}$ hingga diperoleh ekstrak kental etanol etanol (7).

\section{c. Fraksinasi}

Ekstrak pekat atau kental dilarutkan dengan aquadest $100 \mathrm{~mL}$ air yang selanjutnya akan dilakukan pemisahan menggunakan corong pisah dengan pelarut yang tidak saling bercampur satu sama lain yaitu n-heksana yang dilanjutkan dengan etil asetat dengan perbandingan ekstrak cair : pelarut $=1: 1(7)$.

\section{d. Kadar Air}

Sejumlah \pm 50 mg ekstrak ditetapkan kadar airnya dengan menggunakan metode titrimeter karl fischer. Prinsip penetapannya yaitu sampel dititrasi dengan larutan iodine dalam methanol. Reagen lain yang digunakan adalah sulfur dioksida dan piridin. Rasio mutlak antara air dengan iod adalah 1:1 (titik akhir titrasi) (8).

\section{e. Uji Identifikasi senyawa fitokimia \\ 1. Flavonoid}

Sebanyak 0,5 gram ekstrak dengan $2 \mathrm{~mL}$ etanol $70 \%$ dan kemudian ditambahkan serbuk $\mathrm{MgSO}_{4} \quad 0,5$ gram dan 3 tetes $\mathrm{HCl}$ pekat. Flavonoid ditunjukkan dengan terbentuknya warna merah-orange (9).

\section{Saponin}

Sebanyak 0,5 gram ekstrak, dimasukkan dalam tabung reaksi, ditambahkan $10 \mathrm{~mL}$ air panas dan dikocok selama 10 menit, hingga terbentuk busa lalu ditetesi dengan $\mathrm{HCl} 2 \mathrm{~N}$, jika buih tidak hilang dengan penambahan $\mathrm{HCl} 2 \mathrm{~N}$ maka positif mengandung saponin (10).

\section{Alkaloid}

Ekstrak ditimbang 0,5 gram, dimasukkan kedalam tabung reaksi, dilarutkan dengan $2 \mathrm{~mL}$ air dan ditambahkan $5 \mathrm{~mL}$ HCL $2 \mathrm{~N}$. Hasil positif mengandung alkaloid jika ditambahkan 3 tts pereaksi mayer akan membentuk endapan putih dan jika ditambahkan 3 tts pereaksi dragendroff menghasilkan endapan merah jingga (10).

\section{Tanin dan Polifenol}

Sebanyak 0,5 gram ekstrak ditambahkan etanol $70 \%$ sebanyak $2 \mathrm{~mL}$ kemudian ditetesakan $\mathrm{FeCl}_{3}$ sebanyak 3 tetes dan akan terbentuk warna biru, biru-hijau, hijau atau endapan (9).

\section{Steroid}

Sebanyak 0,5 gram ekstrak kental dilarutkan dalam $2 \mathrm{~mL}$ kloroform dalam tabung reaksi yang kering lalu ditambahkan 10 tetes asetat anhidrat dan 3 tetes asam sulfat pekat. Reaksi positif ditunjukkan dengan terbentuknya cincin warna merah kecoklatan pada antar permukaan (11).

\section{f. Penentuan Kandungan Total Fenolik Pembuatan Kurva Baku Asam Galat}

Sebanyak $10 \mathrm{mg}$ asam galat dengan konsentrasi 10, 20, 40, 60, 80 dan 100 ppm, diambil $0,5 \mathrm{~mL}$ masing-masing konsentrasi standar tersebut kedalam tabung reaksi, kemudian ditambahkan $2 \mathrm{~mL} \mathrm{Na}_{2} \mathrm{CO}_{3} 15 \%$ dan divorteks, lalu tambahkan $0,3 \mathrm{~mL}$ reagen Folin Ciocalteau dan divorteks, tambahkan sebanyak 2,2 $\mathrm{mL}$ aquadest. Larutan tersebut dihomogenkan dan diinkubasi selama 30 menit. Semua larutan diukur absorbansinya pada $\lambda$ $736,02 \mathrm{~nm}$, kemudian dibuat kurva kalibrasi hubungan antara konsentrasi asam galat dengan absorbansi.

\section{Penetapan Kadar Total Fenol}

Ekstrak Etanol dan fraksi etanol-air umbi kimpul putih ditimbang sebanyak $50 \mathrm{mg}$, kemudian dilarutkan dengan air kedalam labu ukur $20 \mathrm{~mL}$. Larutan uji diambil masing-masing $0,5 \mathrm{~mL}$, kemudian ditambahkan dengan $2 \mathrm{~mL}$ $\mathrm{Na}_{2} \mathrm{CO}_{3} 15 \%$ dan divorteks, lalu tambahkan 0,3 $\mathrm{mL}$ reagen Folin Ciocalteau dan divorteks, tambahkan sebanyak 2,2 mL aquadest. Larutan tersebut dihomogenkan dan diinkubasi selama 30 menit. Absorbansi larutan sampel dibaca dengan menggunakan spektrofotometri UV-Vis pada $\lambda 736,02 \mathrm{~nm}$. Hasilnya dinyatakan sebagai ekuivalen asam galat dalam $\mathrm{mg} / \mathrm{L}$ ekstrak.

\section{g. Penentuan Aktivitas Antioksidan dengan Metode DPPH}

Pertama-tama dibuat tiga macam larutan yaitu :

Larutan DPPH dibuat dengan konsentrasi $0,002 \%$

Larutan ekstrak etanol $96 \%$ dibuat pengenceran dengan konsentrasi 46,875, 93,75, 187,5, 375 dan 750 ppm dalam metanol p.a.

- Larutan fraksi etanol-air dibuat pengenceran dengan konsentrasi 18,75, 37,5, 75, 150, 300 dan 600 ppm dalam metanol p.a.

Larutan vitamin $\mathrm{C}$ dibuat pengenceran dengan konsentrasi $0,125,0,25,0,5,1,2$ dan 4 ppm dalam metanol p.a.

Larutan yang telah dibuat masing-masing dipipet untuk ekstrak etanol $96 \%$ sebanyak 
$1.875 \mu \mathrm{L}, 3.750 \mu \mathrm{L}, 7.500 \mu \mathrm{L}, 15.000 \mu \mathrm{L}$ dan $30.000 \mu \mathrm{L}$. Fraksi etanol-air dipipet sebanyak $750 \mu \mathrm{L}, 1.500 \mu \mathrm{L}, 3.000 \mu \mathrm{L}, 6.000 \mu \mathrm{L}, 12.000$ $\mu \mathrm{L}$ dan $24.000 \mu \mathrm{L}$. Sedangkan terhadap vitamin C dipipet sebanyak $5 \mu \mathrm{L}, 10 \mu \mathrm{L}, 20 \mu \mathrm{L}, 40 \mu \mathrm{L}$, $80 \mu \mathrm{L}$ dan $160 \mu \mathrm{L}$. Kemudian diitambahkan dengan $2 \mathrm{~mL}$ larutan DPPH setelah itu dihomogenkan dan diinkubasi selama 30 menit. Selanjutnya serapan diukur dengan spektrofotometri UV-Vis pada panjang gelombang 515-520 nm.

\section{h. Analisis Data}

\section{a. Penentuan Nilai IC $_{50}$ (Inhibitory Concentration)} $\%$ inhibisi $=\frac{\text { absorbansi blanko }- \text { absorbansi sampel }}{\text { absorbansi blanko }}$

$$
x \mathbf{1 0 0} \%
$$

Nilai $\mathrm{IC}_{50}$ masing-masing konsentrasi sampel dihitung dengan menggunakan rumus persamaan regresi linier. Persamaan regresi diperoleh dari hubungan antara konsentrasi sampel dan presentase penghambatan aktivitas radikal bebas. Untuk menentukan $\mathrm{IC}_{50}$ ditentukan dengan persamaan $\mathrm{Y}=\mathrm{ax}+\mathrm{b}, \%$ inhibisi sebagai sumbu y dan konsentrasi antioksidan sebagai sumbu $\mathrm{x}$ dengan nilai $\%$ aktivitas antioksidan sebesar $50 \%$ sebagai sumbu y.

\section{i. Teknik Analisis Data}

Analisis data yang diperoleh dalam penelitian ini dianalisis dengan menggunakan metode deskriptif dengan menggunakan program Microsoft Excel. Data akan disajikan dalam bentuk tabel dan grafik serta data yang diperoleh akan dilakukan secara deskriptif yang disertai dengan dengan kurva atau persamaan regresi linear dan narasi.

\section{HASIL DAN PEMBAHASAN Persiapan Sampel}

Hasil determinasi tersebut menunjukkan bahwa tanaman yang diteliti adalah umbi kimpul putih (Xanthosoma sagitafolium (L.) Schott yang termasuk dalam suku Araceae. Hasil pengeringan dari $12 \mathrm{~kg}$ umbi kimpul putih segar diperoleh serbuk kering umbi kimpul putih sebanyak $2.450 \mathrm{~g}$.

\section{Ekstraksi}

Ekstraksi umbi kimpul putih dalam penelitian ini menggunakan metode maserasi dengan menggunakan pelarut etanol $96 \%$ selama $3 \times 24$ jam, Selanjutnya dipekatkan dengan
Parameter yang biasa digunakan untuk menginterpretasikan hasil dari uji aktivitas antioksidan dengan metode DPPH adalah dengan nilai Inhibitory Concentration ( $\left.\mathrm{IC}_{50}\right)$ yaitu konsentrasi yang menyebabkan hilangnya 50\% aktivitas DPPH (Molyneux, 2004). Untuk menghitung nilai $\mathrm{IC}_{50}$ diperlukan data persen inhibisi dari pengujian. Persen inhibisi adalah perbandingan antara selisih dari absorbansi blanko dan absorbansi sampel dengan absorbansi blanko. Perhitungan persentase inhibisi serapan DPPH dengan menggunakan rumus:

menggunakan rotary evaporator sehingga diperoleh ekstrak kental. Hasil ekstraksi diperoleh ekstrak kental berwarna kuning pekat. Ekstrak kental yang diperoleh dari hasil maserasi umbi kimpul putih adalah 34,24 g. Dari proses ekstraksi ini kemudian diperoleh rendemen sebesar $1,3975 \%$.

\section{Fraksinasi}

Ekstrak kental etanol 96\% umbi kimpul putih (Xanthosoma sagitafolium (L.) Schott difraksinasi dengan menggunakan pelarut $n$ heksan dan etil asetat. Fraksinasi dilakukan beberapa kali pengulangan dan dilakukan dengan menggunakan alat yaitu corong pisah, digojok kuat selama \pm 15 menit dan di diamkan sampai terbentuk dua fase yang terpisah. Setelah dilakukan fraksinasi hasil fraksi cair yang sudah terpisah dipekatkan dengan menggunakan Rotary evaporatory sehingga diperoleh hasil akhir berupa ekstrak kental dari fraksi etil asetat, n-heksan dan etanol sisa (sisa dari hasil ekstraksi dengan pelarut $n$-heksan dan etil asetat). Hasil rendemen yang diperoleh dari fraksi etanol-air sebesar 4,7696 g, sedangkan hasil fraksinasi dengan pelarut etil asetat dan $n$-heksan tidak terdapat residu yang tersisa setelah pelarut diuapkan sehingga $\%$ rendemen yang diperoleh hanya $0 \%$.

\section{Kadar Air}

Pemeriksaan kadar air dilakukan dengan menggunakan metode Karl Fischer untuk menentukan jumlah air yang terkandung di dalam ekstrak yang berpengaruh terhadap kestabilan ekstrak. Hasil kadar air pada ekstrak etanol 96\% umbi kimpul putih sebesar 9,29\%. 


\section{Skrining Fitokimia}

Pengujian skrining fitokimia dilakukan bertujuan untuk mengetahui golongan senyawa yang terkandung pada ekstrak etanol $96 \%$ dan fraksi etanol-air umbi kimpul putih
(Xanthosoma sagitafolium (L.) Schott. Berdasarkan hasil dari skrining fitokimia yang terkandung dalam ekstrak etanol 96\% dan fraksi etanol-air umbi kimpul putih dapat dilihat pada tabel di bawah ini.

Tabel 1. Hasil Skrining Fitokimia

\begin{tabular}{lcc}
\hline \multirow{2}{*}{ Golongan Senyawa } & \multicolumn{2}{c}{ Sampel } \\
\cline { 2 - 3 } \multicolumn{1}{c}{ Alkaloid } & \multicolumn{2}{c}{ Ekstrak Etanol 96\% } \\
a. Mayer & + & - \\
b. Dragendroff & - & - \\
Flavonoid & + & + \\
Saponin & + & + \\
Tanin & + & + \\
Steroid & + & Ciocalteau terhadap ekstrak etanol 96\% dan \\
Ket : (+) Mengandung senyawa uji & fraksi etanol-air umbi kimpul putih (Xanthosoma \\
$\quad$ (-) Tidak Mengandung senyawa uji & sagitafolium (L.) Schott .tujuannya yaitu untuk \\
Penentuan Kandungan Total Fenolik & mengetahui adanya kandungan senyawa fenolik \\
$\quad$ Dalam penelitian ini dilakukan pengujian & dalam sampel. \\
total fenol dengan menggunakan metode Folin &
\end{tabular}

Tabel 2. Hasil Persamaan Regresi Linear Asam Galat dan Nilai Total Fenol

Penetapan kandungan fenolik total dimulai dengan membuat kurva baku asam galat untuk menentukan kandungan fenolik total menggunakan persamaan dengan nilai $r$. Nilai $r$ menunjukkan nilai linearitas yaitu korelasi antara konsentrasi dan absorbansi yang dihasilkan. Semakin baik nilai linearitas (nilai $r$ $=1$ atau mendekati 1) maka korelasi juga semakin baik.

Hubungan antara asam galat dan absorbansinya dinyatakan dengan persamaan regresi linear. Pada persamaan regresi linear yang disajikan pada tabel diatas, dimana Koefisien yang baik dilihat dari kesebandingan antara penambahan asam galat dan absorbansi. Persamaan regresi linear diatas dapat digunakan untuk menghitung kandungan fenolik total dengan persamaan regresi linear yang diperoleh. Kadar total fenol dihitung dengan memasukkan data nilai serapan sampel ke dalam persamaan garis regresi linear $\mathrm{y}=\mathrm{bx}+\mathrm{a}$ yang diperoleh dari kurva kalibrasi asam galat.

Dapat disimpulkan dari tabel yang disajikan diatas bahwa pada ekstrak etanol $96 \%$ diperoleh nilai total fenolik yang tinggi dibandingkan dengan fraksi etanol-air. Ekstrak etanol 96\% ini memiliki senyawa teraktif dibandingkan dengan fraksi etanol-air umbi kimpul putih. Menurut penelitian yang dilakukan oleh Wedaswari (2018) perbedaan nilai ini dipengaruhi oleh tingkat kepolaran pelarut yang digunakan terhadap senyawa metabolit yang terdapat pada sampel (12).

Bila kandungan senyawa fenolik di dalam sampel tinggi maka aktivitas antioksidannya akan tinggi. Diduga dengan adanya peningkatan total fenol maka terdapat aktivitas antioksidan yang berlangsung dan semakin besar intensitas 
warna biru maka semakin besar juga kandungan fenolik yang terdapat pada sampel (13).

\section{Penentuan Aktivitas Antioksidan dengan Metode DPPH}

Keberadaan senyawa antioksidan dalam suatu bahan dapat diketahui melalui uji aktivitas antioksidan. Dalam penelitian ini dilakukan pengujian aktivitas antioksidan dengan menggunakan metode serapan radikal DPPH. Selain itu juga diuji vitamin $C$ sebagai pembanding dalam menentukan aktivitas antioksidan. Penggunaan kontrol positif pada pengujian aktivitas antioksidan ini adalah untuk mengetahui seberapa kuat potensi antioksidan yang terdapat pada ekstrak etanol $96 \%$ dan fraksi etanol-air umbi kimpul putih jika dibandingkan dengan vitamin $\mathrm{C}$.

Prinsip kerja dari pengukuran ini adalah kemampuan suatu senyawa antioksidan dalam menangkap radikal bebas. Kemampuan penangkapan radikal berhubungan dengan kemampuan komponen senyawa dalam menyumbangkan elektron atau hidrogen. Setiap molekul yang dapat menyumbangkan elektron atau hidrogen akan bereaksi dan memudarkan DPPH. Senyawa yang aktif sebagai antioksidan mereduksi radikal bebas DPPH menjadi senyawa diphenyl picryl hydrazine. Senyawa DPPH bereaksi dengan senyawa antioksidan melalui pengambilan atom hidrogen dari senyawa antioksidan untuk mendapatkan pasangan elektron (14).

Penentuan panjang gelombang serapan maksimum menggunakan larutan kontrol yaitu DPPH yang dilarutkan dalam metanol tanpa penambahan sampel dengan tujuan untuk mendapatkan panjang gelombang maksimum DPPH tanpa gangguan senyawa lain yang terdapat dalam sampel. Diperoleh hasil Pengukuran DPPH dalam metanol menghasilkan panjang gelombang maksimum pada penelitian ini yaitu 515, $65 \mathrm{~nm}$ untuk ekstrak etanol 96\% dan 515,22 nm untuk fraksi etanol-air umbi kimpul putih. Hasil yang diperoleh termasuk dalam rentang panjang gelombang DPPH yaitu 515-520 nm (15).

Pengujian aktivitas antioksidan dengan parameter yang dapat digunakan untuk menggambarkan aktivitas antioksidan adalah nilai konsentrasi inhibisi $\left(\mathrm{IC}_{50}\right)$. Nilai $\mathrm{IC}_{50}$ merupakan konsentrasi antioksidan yang mampu menghambat $50 \%$ radikal bebas. Nilai $\mathrm{IC}_{50}$ dianggap sebagai ukuran yang baik untuk efisiensi antioksidan senyawa-senyawa murni ataupun ekstrak. Pengujian aktivitas antioksidan secara kuantitatif dilakukan dengan berbagai konsentrasi menggunakan metode DPPH yang selanjutnya dilakukan pengukuran nilai absorbansi menggunakan spektrofotometri UVVis.

Tabel 3. Hasil Uji Aktivitas Antioksidan Masing-Masing Sampel

\begin{tabular}{cccccc}
\hline \multirow{2}{*}{ Larutan Sampel } & Konsentrasi & \multicolumn{4}{c}{ Absorbansi } \\
\cline { 3 - 5 }$(\mathrm{ppm})$ & $\mathrm{U} 1$ & $\mathrm{U} 2$ & $\mathrm{U} 1$ & $\mathrm{U} 2$ \\
& Blanko & 0,268 & 0,268 & & \\
& 46,875 & 0,24 & 0,238 & 10,45 & 11,194 \\
& 93,75 & 0,222 & 0,227 & 17,16 & 15,299 \\
Ekstrak Etanol 96\% & 187,5 & 0,198 & 0,192 & 26,12 & 28,358 \\
& 375 & 0,151 & 0,144 & 43,66 & 46,269 \\
& 750 & 0,084 & 0,086 & 68,66 & 67,910 \\
\hline & Blanko & 0,251 & 0,253 & & \\
\cline { 2 - 5 } Fraksi Etanol-Air & 18,75 & 0,243 & 0,245 & 3,19 & 3,16 \\
& 37,5 & 0,236 & 0,235 & 5,98 & 7,11 \\
& 75 & 0,221 & 0,223 & 11,95 & 11,86 \\
& 150 & 0,197 & 0,193 & 21,51 & 23,72 \\
& 300 & 0,148 & 0,148 & 41,04 & 41,50 \\
& 600 & 0,073 & 0,071 & 70,29 & 71,94 \\
\hline \multirow{2}{*}{ Vitamin C } & Blanko & 0,259 & 0,267 & & \\
& 0,125 & 0,25 & 0,251 & 3,47 & 5,993 \\
& 0,25 & 0,247 & 0,251 & 4,63 & 5,993 \\
& 0,5 & 0,228 & 0,226 & 11,97 & 15,356 \\
& 1 & 0,182 & 0,18 & 29,73 & 32,584
\end{tabular}




\begin{tabular}{ccccc}
2 & 0,086 & 0,094 & 66,80 & 64,794 \\
4 & 0,012 & 0,01 & 95,37 & 95,506 \\
\hline
\end{tabular}

Tabel 4. Hasil Persamaan Regresi Linear dan Nilai $\mathrm{IC}_{50}$ Yang Diperoleh dari masing-masing sampel dan pembanding Vitamin C

\begin{tabular}{|c|c|c|c|}
\hline Larutan Sampel & $\begin{array}{c}\text { Persamaan Regresi } \\
\text { Linear }\end{array}$ & Nilai $\mathrm{IC}_{50}$ & Rata-Rata \\
\hline $\begin{array}{c}\text { Ekstrak Etanol 96\% } \\
\text { Ulangan } 1\end{array}$ & $\begin{array}{c}\mathrm{y}=0,081 \mathrm{x}+9,560 \\
\mathrm{r}=0,993\end{array}$ & 499,26 & \\
\hline Ulangan 2 & $\begin{array}{c}y=0,080 x+10,30 \\
r=0,984\end{array}$ & 496,25 & 497,75 \\
\hline $\begin{array}{l}\text { Fraksi Etanol-Air } \\
\text { Ulangan } 1\end{array}$ & $\begin{array}{c}y=0,116 x+2,811 \\
r=0,996\end{array}$ & 406,80 & \\
\hline Ulangan 2 & $\begin{array}{c}y=0,117 x+3,442 \\
r=0,995\end{array}$ & 397,93 & 402,36 \\
\hline $\begin{array}{l}\text { Vitamin C } \\
\text { Ulangan } 1\end{array}$ & $\begin{array}{c}y=24,94 x+2,590 \\
r=0,979\end{array}$ & 1,86 & \\
\hline Ulangan 2 & $\begin{array}{c}\mathrm{y}=24,11 \mathrm{x}+5,053 \\
\mathrm{r}=0,983\end{array}$ & 1,90 & 1,88 \\
\hline
\end{tabular}

Berdasarkan tabel diatas dapat dilihat dari peredaman radikal DPPH dapat diamati melalui penurunan nilai absorbansi sampel (\% inhibisi) nilai absorbansi dan blanko terhadap ekstrak etanol 96\%, fraksi etanol-air umbi kimpul putih dan Vitamin C. Hasil yang diperoleh akan dihitung dengan menggunakan rumus \% inhibisi. Menurut Muharni (2013) semakin besar konsentrasi maka terjadi peningkatan persen inhibisi (16). Analisis peredaman radikal bebas oleh ekstrak etanol 96\%, fraksi etanol-air dan vitamin $\mathrm{C}$ menunjukkan bahwa semakin meningkat konsentrasi ekstrak maka semakin meningkat aktivitas peredaman DPPH karena semakin banyak atom hidrogen dari ekstrak yang berpasangan dengan elektron pada radikal bebas DPPH sehingga serapan semakin menurun (15).

Dalam pengujian ini dilakukan pengukuran absorbansi blanko yaitu untuk memperoleh \% inhibisi yang digunakan untuk penentuan nilai $\mathrm{IC}_{50}$. Persen inhibisi adalah perbandingan antara selisih dari absorbansi blanko dan absorbansi sampel dengan absorbansi blanko. Setelah diperoleh nilai \% inhibisi dari masing-masing konsentrasi hasil tersebut diplotkan dalam sebuah grafik atau persamaan regresi linear yaitu $\mathrm{y}=\mathrm{bx}+\mathrm{a}, \%$ inhibisi sebagai sumbu y dan konsentrasi sebagai sumbu $\mathrm{x}$ dan diperoleh nilai $\mathrm{IC}_{50}$ yang merupakan konsentrasi dari antioksidan yang dapat menghambat $50 \%$ radikal bebas.

Pembanding yang digunakan sebagai kontrol positif pada penelitian ini yaitu Vitamin C. Vitamin C berfungsi sebagai antioksidan karena secara efektif menangkap radikal bebas terutama ROS atau senyawa oksigen reaktif. vitamin $\mathrm{C}$ bekerja sebagai donor elektron ke dalam reaksi biokimia baik intraseluler maupun ekstraseluler (17).

Hasil pengujian aktivitas antioksidan terhadap nilai $\mathrm{IC}_{50}$ yang diperoleh dari ekstrak etanol 96\% sebesar 497,75 ppm, sedangkan untuk fraksi etanol-air diperoleh nilai $\mathrm{IC}_{50}$ sebesar 402,36 ppm. Dapat disimpulkan bahwa pada ekstrak etanol $96 \%$ dan fraksi etanol-air memiliki nilai $\mathrm{IC}_{50}$ yang menunjukkan kekuatan antioksidan yang sangat lemah dengan nilai $\mathrm{IC}_{50}>200 \mathrm{ppm}$, dimana semakin tinggi nilai $\mathrm{IC}_{50}$ suatu sampel maka menunjukkan semakin lemah 
aktivitas antioksidannya. Pada vitamin C diperoleh nilai $\mathrm{IC}_{50}$ sebesar $1,88 \mathrm{ppm}$ dimana aktivitas antioksidan dari ekstrak etanol $96 \%$ dan fraksi etanol-air umbi kimpul putih lebih rendah dibandingkan dengan aktivitas antioksidan vitamin C. Hal ini dikarenakan struktur vitamin $\mathrm{C}$ mirip dengan struktur monosakarida tetapi mengandung gugus enediol. Pada vitamin $\mathrm{C}$ terdapat gugus enediol yang berfungsi dalam sistem perpindahan hidrogen yang menunjukkan peranan penting dari vitamin ini sebagai antioksidan (18).

\begin{abstract}
Hubungan Total Fenol dengan Antioksidan
Senyawa fenolik diketahui mampu bertindak sebagai antioksidan. Senyawa fenolik merupakan senyawa yang memiliki cincin aromatik dengan satu atau lebih gugus hidroksil yang terikat pada atom karbon dari cincin aromatik tersebut. Gugus hidroksil dalam fenolik berkontribusi secara langsung terhadap aktivitas antioksidan dan memainkan peranan penting dalam penangkapan radikal bebas karena gugus hidroksil dari senyawa fenolik dapat mendonorkan atom hidrogen sehingga dapat menstabilkan senyawa radikal bebas (17).
\end{abstract}

Tabel 5. Nilai Hubungan Total Fenol dan Antioksidan

Sampel
Ekstrak Etanol 96\%
Fraksi Etanol Air
Berdasarkan tabel yang disajikan diatas
bahwa aktivitas antioksidan berbanding terbalik
dengan total fenol. Dimana semakin
meningkatnya total fenol maka nilai antioksidan
IC akan semakin menurun. Hal ini
menunjukkan bahwa semakin tinggi nilai total
fenol maka semakin kuat aktivitas antioksidan
yang dihasilkan.

\section{KESIMPULAN}

Berdasarkan rumusan masalah dapat disimpulkan hasil dari penelitian yang sudah dilakukan sebagai berikut :

1. Metabolit sekunder yang terdapat didalam ekstrak etanol $96 \%$ mengandung senyawa alkaloid, flavonoid, saponin, tanin dan steroid sedangkan terhadap fraksi etanol-air secara kualitatif mengandung senyawa metabolit sekunder flavonoid, saponin, tanin dan steroid.

2. Perhitungan nilai $\mathrm{IC}_{50}$ yang telah diperoleh, menunjukkan bahwa pada ekstrak etanol 96\% umbi kimpul putih memiliki nilai $\mathrm{IC}_{50}$ sebesar 497,75 ppm sedangkan pada fraksi etanol-air umbi kimpul putih memiliki nilai $\mathrm{IC}_{50}$ sebesar 402,36 ppm dan memiliki tingkat kekuatan serta aktivitas antioksidan yang sangat lemah dengan nilai $\mathrm{IC}_{50}>200$ ppm.
$7,09 \mathrm{mg} / \mathrm{g} \quad 497,75 \mathrm{ppm}$

$5,47 \mathrm{mg} / \mathrm{g}$

402,36ppm
3. Perhitungan nilai total fenol yang telah diperoleh, menunjukkan bahwa pada ekstrak etanol 96\% umbi kimpul putih memiliki nilai total fenol sebesar 7,09 mg/g GAE sedangkan pada fraksi etanol-air umbi kimpul putih memiliki nilai total fenol yang lebih rendah yaitu sebesar 5,47 mg/g GAE.

\section{DAFTAR PUSTAKA}

[1] Handajani, N.S. Harini. M., Imaduddin. Z., Ulfa, Z.D.F dan Widiyani. T. 2016. Uji Potensi Umbi Kimpul (Xanthosoma Sagittifolium) Sebagai Bahan Pangan Fungsional Anti Hiperglikemik Dan Anti Hiperkolesterolemia.52-58.

[2] Aldila, F. Anggarwulan. E., dan Solichatun. 2008. Kadar Prolin Dan Polifenol Tanaman Kimpul (Xanthosoma Sagittifolium (L.) Schott) Pada Variasi Intensitas Cahaya Dan Ketersediaan Air.1-16.

[3] Anggarwulan, E. Solichatun., dan Mudyantini, W. 2008. Karakter Fisiologi Kimpul (Xanthosoma Sagittifolium ( L.) Schott) Pada Variasi Naungan Dan Ketersediaan Air. 264- 
29 Diana Sylvia et al., (Aktivitas Antioksidan Ekstrak Etanol Dan Fraksi ...)

268.

[4] Sayuti, K., dan Yenrina, R. 2015.

[11] Harborne, J. B. 1987. Metode Fitokimia: Penuntun Cara Modern Menganalisa Tumbuhan Terbitan Kedua. Bandung: ITB.

[5] Irwan, A. S. 2017. Uji Aktivitas Antimikroba Hasil Fraksinasi Ekstrak Rimpang Jeringau (Acorus Calamus L.) Terhadap Bakteri Patogen. Skripsi. Universitas Islam Negeri Alauddin Makassar : Makassar.

[6] Firman, D. Nurhaeni., dan Ridhay, A. 2016. Aktivitas Antioksidan Ekstrak Umbi Suweg (Amorphophallus Paeoniifolius) Dari Berbagai Tingkat Polaritas [Antioxidant Activity Of Umbi Suweg (Amorphophallus Paeoniifolius) Extract From Various Level Of Solvents Polarity ].2. 61-69.

[7] Candra, N. Setiawan.E., dan Febriyanti, A. 2017. Aktivitas Antioksidan Ekstrak Etanol Dan Fraksi-Fraksi Umbi Eleutherine Palmifolia (L.) Merr Dengan Metode Dpph (The Antioxidant Activity Of Extract And Factions Eleutherine Palmifolia (L.) Merr Bulbs By Dpph Method). 1(1). 1-5.

[8] Gangga, E. Purwati.R., Farida.Y., dan Kartiningsih. 2017. Penetapan Parameter Mutu Ekstrak Yang Memiliki Aktivitas Sebagai Antioksidan Dari Daun Cincau Hijau (Cyclea Barbata L . Miers.) (Determination Of Quality Parameters And Antioxidant Activity Of Cincau Hijau Leaves (Cyclea Barbata L . Miers .).15(2). 236-243.

[9] Hapsari, W.S., Rohmayanti., Yuliastuti.F., dan Pradani, M.P.K. 2017. Skrining Fitokimia Ekstrak Etanol Herba Pegagan Dan Analisa Rendemen. 471-476.

[10] Adhayanti, I. Abdullah.T., dan Romantika,R. 2012. Uji Kandungan Total Polifenol Dan Flavonoid Ekstrak Etil Asetat Kulit Pisang Raja (Musa Paradisiaca Var. Sapientum).146-152.

[12] Wedaswari, I.A.I. 2018. Aktivitas Antioksidan Ekstrak Etanol Dan Fraksi Daun Sirih Merah (Piper Crocatum) Dengan Metode Rancimat Dan Identifikasi Dengan Lc-Ms. Skripsi. Universitas Pertanian Bogor. Bogor.

[13] Dungir,S.G., Katja.D.G., dan Kamu, M.S. 2012. Aktivitas Antioksidan Ekstrak Fenolik Dari Kulit Buah Manggis (Garcinia Mangostana L.). 1(1). 11-15.

[14] Pokorny, J., Yanishlieva. N., dan Gordon, M. 2001. Antioxidants In Food. Cambridge England: Woodhead Publishing Limited.

[15] Molyneux, P. 2004. The Use Of The Stable Free Radical DiphenylpicrylHydrazyl (Dpph) For Estimating Antioxidant Activity.

[16] Muharni., Elfita., dan Amanda. 2013. Aktivitas Antioksidan Senyawa (+) Morelloflavon Dari Kulit Batang Tumbuhan Gamboge (Garcinia Xanthochymus). 265-268.

[17] Adawiyah., Sukandar.D., dan Muawanah, A.2015. Aktivitas Antioksidan Dan Kandungan Komponen Bioaktif Sari Buah Namnam. 130-136.

[18] Lung.J.K.S., dan Destiani, D.P. 2015. Uji Aktivitas Antioksidan Vitamin A, C, E Dengan Metode Dpph. 53-62. 